\title{
Erik Erikson and the Church: Corporate Worship that Sustains through Crises
}

\author{
Robert Pendergraft \\ University of Mary Hardin-Baylor
}

\begin{abstract}
The work of developmental psychologist Erik Erikson (1902-1994) has profound implications for understanding and ministering to the different generations represented in the church. Erikson has garnered attention from religious writers in recent years including Eric Geiger, Lee Steele, and Catherine Stonehouse because of the correlation of his work with religious thought and values. Though Scripture must remain the standard by which worship is governed, a congregation will benefit from consideration of Erikson's work since it concretely represents the social and developmental interactions that are observable throughout the Bible and in society at large. The following paper will examine the eight life stages outlined by Erikson to discover how active participation in corporate worship meets the identity crises indicative of each stage. It will further give means by which corporate worship can be constructed to minister to those in the congregation at different life stages. Rightly understood, these crisis points should be viewed by the church as opportunities for spiritual development. When worship meets the needs of an individual going through one of the eight life crises, it can help him or her move to the next developmental stage as he or she grows toward maturity. Corporate worship is instrumental in forming the congregation as ever maturing followers of Christ and the theory of Erikson gives the local church a concrete framework to spur congregants on toward spiritual maturity.
\end{abstract}

Keywords: Erik Erikson, worship, development, spiritual development, life stages

The work of the developmental psychologist and psychoanalyst Erik Erikson (1902-1994) has profound implications for understanding and ministering to the different generations in the church. Perhaps no work in the field of developmental psychology is as profitable for the church as Erikson's. Because of the ease with which his work integrates into church life, Erikson has garnered attention from Christian authors in recent years. Eric Geiger, Vice President of Resources for Lifeway Christian Resources, uses Erikson's work to evaluate the state of the church: "According to Erikson, if a teenager does not walk away from his adolescent years with a clear sense of who he is, he will never have a healthy personality. He will be stuck... Sadly, many Christians are stuck in an adolescent faith” $(2008,6)$. Geiger is referring to the identity confusion versus identity crisis that will be examined later in this paper. Catherine Stonehouse, longtime professor at Asbury Theological Seminary, relies heavily on the work of Erikson to lay out the foundations of children's faith (1998, 43-68). Additionally, Lee Steele wrote a chapter, “The Power of Erikson,” in which he uses Erikson's theories to tailor discipleship to the individual congregant (1995, 91-103). These uses of Erikson's work, among others, lead Brenna Mae

Robert Pendergraft, Ph.D., Assistant Professor, College of Visual and Performing Arts, Department of Music, University of Mary Hardin-Baylor, USA; main research field: Intergenerational Worship. 
Whitley to assert in her dissertation "that theories such as Erikson's are now the assumed framework from which many seminaries train future ministers of the gospel to engage in Christian education” $(2009,26)$. Though Scripture must remain the primary shaping force in understanding development and maturation, Erikson's work concretely represents the social and developmental interactions that are observable of those in different stages of life and faith throughout the Bible and in society at large.

At the core of Erikson's work is the concept of an individual moving through eight identity crises. Adams and Berzonsky show that this usage of the term "identity crisis" does not refer to a looming "catastrophe, but rather a critical turning point in the life history of an individual, in which development can only move forward by taking a new directional course" $(2008,207)$. The church is often a place of refuge when national crisis or personal crisis strikes, with the help of Erikson, the church may become a place of shelter and growth in the personal developmental crises as well. Cully—using the term crisis as Erikson does—notes that "crisis is an opportunity for religious development” $(1983,201)$. The church has congregants at each life stage within its flock, and it must understand the crisis points of human development in order to fully minister to those facing these transition points of life. More specifically, the church must understand how corporate worship is uniquely positioned so that every developmental crisis can be addressed and overcome within its context.

The following paper will examine the eight life stages outlined by Erikson to discover how active participation in corporate worship meets the identity crises indicative of each stage. It further gives means by which corporate worship can be constructed to minister to congregants at different life stages. Rightly understood, these crisis points should be viewed by the church as opportunities for spiritual growth and development. Corporate worship is perhaps the most significant act in forming the congregation as ever maturing followers of Christ, and the developmental theory of Erikson gives the local church a concrete framework to urge congregants toward spiritual maturity.

\section{Erikson and Scripture}

The work of developmental and educational psychologists must not be the primary factor to determine the structure and design of corporate worship, but it can be beneficial to the church when viewed through the lens of Scripture. At times, the work of these psychologists is categorically dismissed because its origins are from outside the church. This distrust is so great that the church has, on occasion, accused psychology of undermining religious and educational instruction. Berliner describes this unwarranted fear by stating, "the Christian Right believes that educational psychologists have played a role in the perversion of the schools, destroying their central mission, the communication of factual knowledge, in order to promote secular humanist objectives” (1997, 386). These same Christians who believe educational psychologists played a role in ruining the purpose of schools, would also most assuredly object to applying the work of any developmental or educational psychologist to the church.

At the opposite end of the spectrum are a group of Christians who look to secular educational principles as the primary means for delivering the content of the Gospel. In the decades following World War I, progressive religious education took hold in many churches. Hudson and Corrigan cite George A. Coe's Social Theory of Religious Education (1917) in explaining that the purpose of the educational program of the church was "the growth of the young toward and into mature and efficient devotion to the democracy of God, and happy self-realization therein" $(1992,356)$. The focus on expedient ways of instructing children failed to maintain the primacy of Scripture in both content and method. The effects of progressive religious education are seen in the 
church-growth oriented ministries of the present church. Though these ministries invoke secular models as their fountainhead, the particular philosophies to which they look seem to be incompatible with Scripture.

Erikson was not a deeply religious man. His writings though often align with Scripture because he predominantly "thought from within Judeo-Christian monotheism" (Hoare 2002, 87). Hoare further explains that Erikson "wrote he had been drawn to the teachings of Jesus from an early age. In part, Erikson said, his sense of the 'credal immediacy' of the Gospels, of the way of life of the first Christians, and of Christianity's 'core values' originated in his youth” $(2002,87)$. Though belief in God is not necessarily a prerequisite for producing a framework the church may find beneficial, it is more likely this will be the case coming from a Christian because of the shared worldview and values that emerge in his writings. Erikson, though not a professing Christian, was heavily influenced from an early age by Judeo-Christian thought. His principles as outlined below have been shown by multiple authors to be congruent with the teachings of Scripture. ${ }^{1}$

Scripture is not to serve as a textbook on developmental psychology, however, mature formulations of developmental psychology that reflect Scripture can aid the church in moving the congregation toward spiritual growth. Just as science may deepen our understanding of God's creation, so too does developmental psychology deepen the understanding of how people grow and mature. From the time of the early church, there has been recognition that learning is beneficial as long as it is consistent with the standard set forth in Scripture. Origen articulates such a position in Book III of Origen against Celsus:

Truly it is no evil to have been educated, for education is the way to virtue; but to rank those amongst the number of the educated who hold erroneous opinions is what even the wise men among the Greeks would not do. On the other hand, who would not admit that to have studied the best opinions is a blessing? But what shall we call the best, save those which are true, and which incite men to virtue? Moreover, it is an excellent thing for a man to be wise, but not to seem so, as Celsus says. And it is no hindrance to the knowledge of God, but an assistance, to have been educated, and to have studied the best opinions, and to be wise. (Roberts and Donaldson 2004, 484)

This paper stakes such a mediated position that maintains the centrality of Scripture while allowing for critical evaluation of the work of Erikson. The theories and postulations set forth in this paper complement the Bible's teaching on education and development. Erikson's work places concepts found in Scripture into observable stages and explains knowledge and skill acquisition in terms of visible processes. These confirmations of scriptural concepts are helpful to the church in practical application and evaluation of its practical philosophy of corporate worship.

\section{The Eight Identity Crises}

The work of Erikson demonstrates that generational isolation hinders movement through the stages. Erikson explains, "we must not overlook what appears to be a certain abrogation of responsibility on the part of the older generation in providing those forceful ideals which must antecede identity formation in the next generation” (1968, 30). Younger generations need the structure and examples of older generations. Gobbel directly applies this to the congregation explaining "Adults in gathered community are faith-models for the children" $(1979,574)$.

It is not only the younger generations that suffer when generational isolation invades the sanctuary. Erikson writes, 
In our country useless old things, as we know, are taken to the dump. We have, however, introduced "recycling," which extends the usefulness of old objects for a while and keeps us from overburdening the land with enduring deposits of debris. We don't take our old folks to the dump, but we certainly don't do enough toward their recycling. $(1997,115)$

All generations need one another to thrive. The analysis below will demonstrate that the church needs all generations to worship together. Dann demonstrates that "Excluding anyone—including children—can be a great mistake... It would not be a surprise if bonding was impaired, or if the children attached little value to the family and its gatherings” $(1985,13)$. Excluding youth, adults, or senior adults also is a grievous error, for their exclusion forever alters the family photo of the church universal. The following sections will identify the eight crises discussed in the writings of Erikson and demonstrate how the church can minister through corporate worship to those individuals at each life stage.

\subsection{Basic Mistrust versus Trust-The Crisis of Infancy}

The initial stage in Erikson's model covering the earliest year of life is basic trust versus mistrust. During this stage, the infant develops a strong bond with the mother who ensures his or her needs are met. Erikson writes: "The mother must represent to the child an almost somatic conviction that she (his first 'world') is trustworthy enough to satisfy and regulate his needs" $(1987,600)$. The young child has no way of pursuing means to satisfy his or her needs; rather, the child is dependent on others to provide those necessities. Historically, the only person who could provide the need of food was the mother; hence, she has been, throughout history, the most important person in the life of the newborn child.

The baby's parents, especially his or her mother, best meet his or her essential needs. Erikson explains that the "infant's first social achievement, then, is his willingness to let the mother out of sight without undue anxiety or rage, because she has become an inner certainty as well as an outer predictability" (1993, 247). Erikson emphasizes, "The resolution of the first psychosocial crisis is performed primarily by maternal care" (1987, 600). Erikson also explains that the religious faith of the parents is communicated to the child by fulfilling their need of trust. ${ }^{3}$ The church, then, must endeavor to support the family so that the mother can meet the needs of her child. ${ }^{4}$ While the specifics of this may vary depending on the context of the local church, the child's parents, and particularly the mother, should be actively engaged in the care of the infant while at church.

The congregation too needs to observe and participate in this stage of development for better understanding the process of faith formation. Erikson explains,

The parental faith which supports the trust emerging in the newborn, has throughout history sought its institutional safeguard (and, on occasion, found its greatest enemy) in organized religion. Trust born of care is, in fact, the touchstone of the actuality of a given religion. All religions have in common the periodical childlike surrender to a Provider or providers who dispense earthly fortune as well as spiritual health... the insight that individual trust must become a common faith, individual mistrust a commonly formulated evil, while the individual's restoration must become part of the ritual practice for many, and must become a sign of trustworthiness in the community. $(1993,250)^{5}$

This concept is found clearly outlined in the synoptic gospels. ${ }^{6}$ Jesus places a child among his disciples then tells them "unless you turn and become like children, you will never enter the kingdom of heaven. Whoever humbles himself like this child is the greatest in the kingdom of heaven” (Matt. 18:3-4). ${ }^{7}$ The presence of children with their parents in worship allows the infant to develop the trust he or she requires and allows the congregation to be constantly reminded of the dependence of that child on his or her parents in the same manner in which the congregants are to be reliant on God. 


\subsection{Autonomy versus Shame and Doubt-The Crisis of Early Childhood}

During early childhood, children must develop the skills to do things themselves rather than relying solely on the aid of others. The conflict where this struggle for self-sufficiency is most noticeably showcased is in toilet training. Erikson explains: "The over-all significance of this stage lies in the maturation of the muscle system... and the enormous value with which the still highly dependent child begins to endorse his autonomous will" $(1993,68)$. The parent's role in this maturation is one of consistency and patience: "be firm and tolerant with the child at this stage, and he will be firm and tolerant with himself. He will feel pride in being an autonomous person; he will grant autonomy to others; and now and again he will even let himself get away with something” (1993, 73). Conquering this stage is essential to the child's ability to function in a group or society.

The child's parents remain the greatest influence on the child through this period of mastering physical skills and developing a sense of autonomy. As the parents communicated their religion through the relationship with their child in the previous stage, the concepts of law and justice, which have their foundations in the Word of God, underlie this stage. ${ }^{8}$ There is opportunity at this stage to impress on the child that God is the creator and sustainer of all things. The parents can reinforce this concept in daily life, integrating it with everyday activity. Though observing parents throughout the week is valuable, the opportunity for children to observe their parents in corporate worship is irreplaceable.

Corporate worship additionally gives the opportunity for others in addition to the parent to affirm the child. This is a sacred responsibility that cannot be taken lightly because, as the ethos of corporate worship "encourages [the child] to 'stand on his own feet,' it must protect him against meaningless and arbitrary experiences of shame and or early doubt” (Erikson 1993, 252). Worship can be affirming, exposing the child to new experiences and allowing him or her to begin mimicking the actions of those in the congregation, and move the child toward the next developmental task. Worship can also be defeating by holding this young child to unrealistic standards and disciplining in such a manner that brings about shame in the child. The parents, ministers, and congregants shape the experience in their response to the young child. Encouraging and gentle responses move the child forward, but shameful, harsh reactions create roadblocks to development.

\subsection{Initiative versus Guilt-The Crisis of the Preschool Age}

Having developed the skills to function semi-independently, the preschool age child "must now find out what kind of a person he is going to be" (Erikson 1994, 78). ${ }^{9}$ To answer this question, the child "tries to comprehend possible future roles, or at any rate to understand what roles are worth imitating” (Erikson 1994, 79). Having observed a model for what the child may grow up to be, he "begins to comprehend his expected role in the adult world and to play out roles worth imitating. He develops a sense of initiative” (Erikson 1987, 603). It is, therefore, imperative that children during this stage observe corporate worship. The child observing his or her parents worshiping will desire to replicate that act, opening another door for conversing about the meaning of worship.

The conscience of the child begins emerging during this developmental period. According to Erikson, "The child now feels not only ashamed when found out but also afraid of being found out. He now hears, as it were, God's voice without seeing God. Moreover, he begins automatically to feel guilty even for mere thoughts and for deeds which nobody has watched" $(1994,84)$. The heightened awareness of conscience makes this an important stage for the spiritual development of the child. Erickson explains that "the child is at no time more ready to learn quickly and avidly, to become bigger in the sense of sharing obligation and performance than 
during this period of his development” $(1993,258)$. For the first time, an understanding of disobedience, or sin, exists, and the child believes him or herself to be morally culpable in the commission of sin. Erikson explains the child's rudimentary understanding as follows:

Where the child, now so ready to overmanipulate himself, can gradually develop a sense of moral responsibility, where he can gain some insight into the institutions, functions, and roles which will permit his responsible participation, he will find pleasurable accomplishment in wielding tools and weapons, in manipulating meaningful toys —and in caring for younger children. $(1993,258)$

A great opportunity to teach spiritual truths to the child exists, particularly in light of his or her newfound conception of right and wrong. That opportunity is complemented by the child's "responsible participation" in the worship of the church and in using the "tools" of the church's worship.

\subsection{Industry versus Inferiority-The Crisis of School-Age Children}

The characteristic task of the fourth developmental stage is academic work. During this period, children identify themselves by what they learn. According to Erikson: "In all cultures, at this stage, children receive some systematic instruction, although... it is by no means always in the kind of school which literate people must organize around special teachers who have learned how to teach literacy" $(1993,259) .{ }^{10}$ This fallacy of constant age segregation around specialized teachers has led to a faulty application of developmental psychology in many churches. It is assumed by some that the only way to transmit information to school-age children is to follow the academic classroom model of public educational institutions; however, this is not the only means to accomplish the end product of a biblically literate child. Too often this manner of instruction sacrifices a love of God for a love of knowledge about God, whereas application of biblical knowledge occurs when children join others in worship.

The child develops through instruction a sense of industry, or a need to do things. In terms of religious instruction, the ultimate purpose or fundamental activity in which one may participate is worship. According to Erikson, "industry involves doing things beside and with others" $(1994,93)$. The ultimate goal of this stage, in religious terms, is participation with the family and congregation in worship. It is for this task that the child has been preparing through the previous stages, and in this task that the child fulfills his or her desire to become a more fully accepted member of the community. For this life stage, competence is understood to be "the free exercise (unimpaired by an infantile sense of inferiority) of dexterity and intelligence in the completion of serious tasks. It is the basis for cooperative participation in some segment of the culture” $(1987,605)$. There is no more serious task for the church than that of corporate worship. Thereby, the child's participation in worship as a co-equal is a signifier of mastery of this stage.

\subsection{Identity versus Identity Confusion-Adolescence}

The fifth stage is commenced by the onset of puberty, which, according to Erikson, ushers the older child into a stage of adolescence. Such an intermediary stage of adolescence or youth is not found on the pages of Scripture; however, this period might be seen as one of apprenticeship and developing the skills and trade necessary to support a family. Societal structures have changed creating this nebulous time of transition between childhood and adulthood. The developmental task of this period is still accurate whether pubescent individuals are viewed as young adults or in this transitory stage because the developmental task of puberty must be met before progressing to the next stage, which has as its end marriage and family. 
In the struggle for identity, "an ideological seeking after an inner coherence and a durable set of values can be detected" (Erikson 1987, 605). This stage serves as the gateway for the transmission of these ideals to their generation. ${ }^{11}$ It is a time of accepting what their heritage has passed on to them and challenging the aspects of that heritage that seems unjust.

Putting groups of adolescents together that are all struggling to navigate their identity will lead to pettiness and role confusion within the group. Erikson explains:

Young people can also be remarkably clannish, and cruel in their exclusion of all those who are "different," in skin color or cultural background, in tastes and gifts, and often in such petty aspects of dress and gesture as have been temporarily selected as the signs of an in-grouper or out-grouper. It is important to understand (which does not mean condone or participate in) such intolerance as a defense against a sense of identity confusion. $(1993,161)^{12}$

The church's understanding these intolerances as identity confusion should make the church eager to shepherd the students away from these prejudices.

The greatest way identity can be grounded is through the influence of those who have successfully navigated this stage already. Erikson explains, "it is only having a genuine sense of who we are that keeps our feet on the ground and our heads up to an elevation from which we can see clearly where we are, what we are, and what we stand up for" $(1997,110)$. Mature believers who have grounded their identity in Christ can walk alongside those younger than they who are searching for a place of acceptance and point them toward the right defining source of their identity, the unchanging gospel of Jesus Christ. This relationship between generations is vital and is strengthened and affirmed when worshiping together in a corporate setting.

\subsection{Intimacy versus Isolation-The Crisis of Young Adulthood}

Erikson signifies the beginning of adulthood with the individual reaching biological maturity. The ideal scenario for adults moving through this phase is that as they grow in who they are, they find a spouse that also has established an identity, and together they continue to grow forging an identity as a family unit. Intimacy prior to an established identity, though, may derail the developmental task of this life stage. Erikson explains, "When young people have heterosexual relations before the identity crisis is solved, either with simple social sanction or by early marriage... difficulties may result, and divorces may ensue in considerable numbers" (1987, 642). These observations make the church's interactions with adolescents during the previous life stage even more crucial.

The church must do whatever is necessary to help students ground their identity in Christ. Adolescents in the church moving into the intimacy conflict without Christ as their identity will idle in their growth during the young adult years. Erikson explains that when two individuals marry but fail to achieve this growth and unity, "a change in mate is rarely the answer but rather some wisely guided insight into the fact that the condition of a true twoness is that one must first become oneself” $(1994,101)$. This again points to the need for the church to take on the significant task of walking with students and young adults to maturity, which is aligning their self-worth with the redemptive work of Christ.

The intimacy fostered in this stage is not only to another individual, but also is intimacy, or closeness, in other relationships. Erikson demonstrates that during this stage "We are what we love" $(1968,138)$. From a religious perspective, this is an opportunity to further galvanize the salvific relationship. Grounding one's identity in Christian worship strengthens the identity between the individual and Christ, producing a more committed and mature follower of Christ. 


\subsection{Generativity versus Stagnation-The Crisis of Middle Adulthood}

The challenge of generativity can be summed up as "primarily the concern with establishing and guiding the next generation" (Erikson 1987, 607). While bearing children does play a role in this stage, that is not the only focus of generativity. Erikson explains that there are individuals "who, from misfortune or because of special and genuine gifts in other directions, do not apply this drive to offspring of their own, but to other forms of altruistic concern and of creativity, which may absorb their kind of parental drive” $(1968,138)$. Though some people may not have children of their own, the need to pass on to the next generation is a void that is found in their lives. Erikson emphasizes this concept stating "the fashionable insistence on dramatizing the dependence of children on adults often blinds us to the dependence of the older generation on the younger one. Mature man needs to be needed, and maturity needs guidance as well as encouragement from what has been produced and what must be taken care of" (1993, 266-7).

An excellent opportunity exists for parents and those without children to shepherd the next generation together in corporate worship. There is no more important truth for Christian adults to pass to children than what it means to become a worshiper. When children are kept separated from adults, those adults miss the opportunity to pour into children's lives by action and example. Bouwsma summarizes, "Christianity has usually seen the individual in close and organic community with others... The primary experiences through which the Christian grows are social experiences. One encounters Christ and the opportunity to serve him in others" $(1978,92)$. The missed opportunity when adults and children are not in corporate worship together withholds from the adults an occasion for them to find meaning through investing the legacy of their faith in the next generation.

\subsection{Integrity versus Despair and Disgust-The Crisis of Late Adulthood}

Late in life, worth is not measured by the number of sermons one heard preached, the number of prayers prayed, or the number of songs one sang uninterrupted by a baby's cry; worth is measured by the investments made in others and the things one creates. Erikson states: "Only he who in some way has taken care of things and people and adapted himself to the triumphs and disappointments of being, by necessity, the originator of others and the generator of things and ideas-only he may gradually grow in the fruit of the seven stages" (1994, 104). Older adults need to look at their lives and realize they have left a legacy for the future. The legacy of adults in the church is a new generation of worshipers to continue worshiping even after the older adults are no longer there. Erikson notes the impact of senior adults on young children writing "healthy children will not fear life if their elders have integrity enough not to fear death" (1993, 269). Separating children, youth, and even young adults from corporate worship deprives the older adults of the church from leaving this legacy and prevents the children, youth, and young adults from having the opportunity to be impacted by the older generations.

The interaction of children, adolescents, and adults creates a self-fulfilling cycle, moving each one toward the ultimate reward of ego integrity. Erikson notes "Every human being is headed for old age, with all its joys and sorrows. But how can we learn from our elders how to prepare for the end of life, which we all must face alone, if our role models do not live among us?” $(1997,118)$. Each life stage needs interaction with the other seven stages, but none more so than needing to interact with those at the end of life. Corporate worship provides an opportunity for that interaction. 


\section{Constructing Corporate Worship to Minister to Different Stages}

People at different developmental stages need one another. The work of Erikson has demonstrated the importance of having influence from individuals other than one's generational peers. Corporate worship must be intergenerational to help individuals move through the different crisis points of life. I will now draw three implications from this examination of Erikson's work.

Spiritual formation is closely linked to physical and psychosocial development. Spiritual development is not just an aggregate of physical and psychosocial development, but "healthy psychosocial development is an important part of spiritual formation. It sets the stage for a relationship with God” (Stonehouse 1998, 63). Stonehouse explains, "Erikson saw human development as the process of the body and the ego developing in interaction with the social context. None of these elements can be fully understood in isolation from the others, and all must be considered to comprehend human development” $(1998,45)$. The church must then be sensitive to the physical and mental capacities of those in the congregation, both young and old, when designing corporate worship that fosters spiritual formation. All congregants should have parts of the service in which they can cognitively and physically participate. ${ }^{13}$

The developmental theory of Erikson necessitates convergence rather than separation in worship. This paper has demonstrated that individuals at each stage need people from the other stages to assist them in navigating the developmental crisis which they face. Worship that aids in meeting those crises will bring all ages together rather than separate them into age-banded groups. Age segregation in worship stunts maturation and growth of the congregants by not embracing the needs of those at varying developmental stages. This is not just a critique of those that separate children from the service, but also is directed toward any generational marketing be it toward children, youth, young adults, or senior adults.

The work of Erikson shows that we should embrace an honest view of the aging process. Developmental language is prominent throughout Scripture with symbolism of birth and childhood through the life cycle to death. It is, therefore, important for the church to be forthright in their presentation of the lifecycle by embracing those both at the beginning and the end of life. Families often live separated by distance or relationships from previous generations, so the church congregation has an opportunity to serve as a surrogate standing in place for the missing generations whether they be young or old. The whole church worshiping together allows for transparency in the aging process and fills the generational gaps in congregants lives that may prevent their own development while giving a more robust understanding of the generational analogies found in Scripture.

In examining eight unique age stages, this paper has demonstrated that each stage is interdependent on the others for crisis mastery. The church, however, often seeks to meet developmental crises by providing separate experiences for each age group. It is regrettable that "many pastors and teachers seek to understand adult spiritual formation in isolation from childhood spiritual formation. But our life stories are all of one piece, the experiences and responses of childhood are the foundation stones of personality and faith" (Stonehouse 1998, 62). The church will do well to shift her ministry philosophy, particularly in corporate worship, to one that embraces all developmental stages in the same service for mutual edification of congregants at each life stage. 


\section{Notes}

1. C.f. Pendergraft 2015, Stonehouse 1998; and May 2005.

2. Emphasis original.

3. "It is not the psychologist's job to decide whether religion should or should not be confessed and practiced in particular words and rituals. Rather the psychological observer must ask whether or not in any area under observation religion and tradition are living psychological forces creating the kind of faith and conviction which permeates a parent's personality and thus reinforces the child's basic trust in the world's trustworthiness... Whosoever says he has religion must derive a faith from it which is transmitted to infants in the form of basic trust; whosoever claims that he does not need religion must derive such basic faith from elsewhere" (Erikson 1994, 66-67).

4. This is especially critical of the older infant. Erikson explains that "at around eight months the child seems to be somehow more aware, as it were, of his separateness: This prepares him for the impending sense of autonomy. At the same time he becomes more cognizant of his mother's features and presence and of the strangeness of others. Sudden or prolonged separation from his mother at that time apparently can cause a sensitive child to experience an aggravation of the experience of division and abandonment, arousing violent anxiety and withdrawal” (1994, 74). Emphasis original.

5. Emphasis original.

6. C.f. Matthew 18:1-6, Mark 9:33-37, and Luke 9:46-48.

7. All Scripture citations are from the ESV unless otherwise noted.

8. "We have related basic trust to the institution of religion. The lasting need of the individual to have his will reaffirmed and delineated within an adult order of things which at the same time reaffirms and delineates the will of others has an institutional safeguard in the principle of law and order... A sense of rightful dignity and lawful independence on the part of adults around him gives to the child of good will the confident expectation that the kind of autonomy fostered in childhood will not lead to undue doubt or shame in later life" (Erikson 1993, 254). Emphasis original.

9. Emphasis original.

10. Emphasis original.

11. "For it is through their ideology that social systems enter into the fiber of the next generation and attempt to absorb into their lifeblood the rejuvenative power of youth. Adolescence is thus a vital regenerator in the process of social evolution, for youth can offer its loyalties and energies both to the conservation of that which continues to feel true and the to the revolutionary correction of that which has lost its regenerative significance” (Erikson 1968, 134).

12. Emphasis original.

13. For practical ideas of ways to include all generations in corporate worship see Holly Catterton Allen and Christine Lawton Ross. Intergenerational Christian Formation: Bringing the Whole Church Together in Ministry, Community and Worship (Downers Grove: IVP Academic, 2012), 273-86.

\section{Works Cited}

Adams, Gerald R. and Michael Berzonsky, eds. Blackwell Handbook of Adolescence. Malden: Blackwell Publishing Ltd., 2008.

Berliner, David C. "Educational Psychology Meets the Christian Right: Differing Views of Children, Schooling, Teaching, and Learning.” Teachers College Record 98.3 (1997): 381-416.

Cully, Iris V. “A Theology of Children.” Review \& Expositor 80.2 (1983): 201-10.

Dann, L. Philip. “Taking Children Seriously: Ministering to Children Needs More Emphasis in Churches.” Christian Ministry 16.1 (1985): 11-14.

Erik, H. Erikson. A Way of Looking at Things: Selected Papers from 1930 to 1980. New York: W. W. Norton \& Company, 1987.

---. Childhood and Society. New York: W. W. Norton \& Company, 1993.

---. Identity and the Life Cycle. New York: W. W. Norton \& Company, 1994.

---. Identity: Youth and Crisis. New York: W. W. Norton \& Company, 1968.

---. The Life Cycle Completed: Extended Version with New Chapters on the Ninth Stage of Development. New York: W. W. Norton \& Company, 1997.

Geiger, Eric. Identity: Who You Are in Christ. Nashville: B \& H Publishing Group, 2008.

Gobbel, Roger and Gertrude G. Gobbel. “Children in Worship.” Religious Education 74.6 (1979): 571-82.

Hoare, Carol Hren. Erikson on Development in Adulthood: New Insights from the Unpublished Papers. New York: Oxford University Press, 2002.

Hudson, Winthrop S. and John Corrigan. Religion in America. Upper Saddle River: Prentice-Hall, 1992.

May, Scottie, et al. Children Matter: Celebrating Their Place in the Church, Family, and Community. Grand Rapids: Eerdmans, 2005. 
Pendergraft, Robert Brian. A Credobaptist Defense for Including Children in Corporate Worship through a Biblically Appropriate Application of Developmental Psychology. 2015. Southwestern Baptist Theological Seminary, PhD dissertation.

Roberts, Alexander and James Donaldson, eds. Ante-Nicene Fathers, Vol. 4. Peabody: Hendrickson Publishers, 2004.

Steele, Lee. “The Power of Erikson.” Ed. James C. Wilhoit. Nurture that Is Christian. Wheaton: Victor Books, 1995. 91-103.

Stonehouse, Catherine. Joining Children on the Spiritual Journey: Nurturing a Life of Faith. Grand Rapids: Baker Academic, 1998.

William J. Bouswma. “Christian Adulthood.” Ed. Erik H. Erikson. Adulthood. New York: W. W. Norton and Company, 1978. 81-96.

Whitley, Brenna Mae. Applying a Comprehensive-Internal Model for the Evaluation of Social-Scientific Research to the Identity Crisis Stage of Erik Erikson's Developmental Theory. 2009. The Southern Baptist Theological Seminary, PhD dissertation. 